\title{
Debt Servicing and Sectoral Economic Growth in Kenya
}

\author{
Brenda Molonko ${ }^{1}$, Ambrose Jagongo ${ }^{2}$, Job Omagwa ${ }^{2}$ \\ ${ }^{1}$ Finance Officer, State Department for Wildlife, Kenya \\ ${ }^{2}$ Kenyatta University, School of Business, Kenya \\ Correspondence: Brenda Molonko, State Department for Wildlife, Kenya.
}

Received: March 13, 2018

doi:10.11114/aef.v5i3.3244
Accepted: April 24, $2018 \quad$ Available online: April 26, 2018

URL: https://doi.org/10.11114/aef.v5i3.3244

\begin{abstract}
The study objective was toestablish the effect of debt servicing on sectoral economic growth as well as the moderating effect of inflation on the relationship between debt servicing and sectorial economic growth in Kenya. The study employed Auto Regressive Distributed Lag model. Eleven sectors that receive government expenditure were analyzed while adopting positivist philosophy and a causal research design. The Study period covered the year 2006 to the 2015.Secondary data for the study period were collected from Statistical Abstracts of Kenya National Bureau of Statistics and Debt Servicing Reports from Kenya National Treasury. Panel Stationarity Test and Heterogeneity Test were conducted as preliminary tests whereas Hausman Test was carried out to choose efficient estimator from Pooled Mean Group, Dynamic Fixed Effects and Mean Group Estimators. The study established that in the long run, debt servicing has a significant effect on sectoral economic growth. In addition, the study established that inflation has a significant moderating effect on the relationship between debt servicing and Sectoral economic growth in the long run at the significance level of 0.05 . The study concluded that debt servicing has a significant effect on sectoral economic growth in Kenya in the long run and no effect in the short run. Additionally, inflation enhances the influence of debt servicing on sectoral economic growth in the long run. The study further confirms that Kenya is not facing a debt overhang problem. The study recommends that if the government must borrow, the loans should be concessional in nature with long term repayment periods. The government should ensure that reasonable levels of inflation are achieved.
\end{abstract}

Keywords: inflation, sectoral economic growth, debt servicing

\section{Introduction}

\subsection{Background to the Study}

There is a global concern over rising debt level both in developed and developing countries. Countries that were hit by the year 2008 global financial crisis like Spain, Ireland, Italy and Greece have been struggling with high levels of debt with their debt ratios being $100.2 \% 121 \%, 135.2 \%$ and $177.2 \%$ respectively. Kenya's debt to GDP ratio was at $50 \%$ as at December, 2013 (World Bank, 2015). International Monetary Fund indicates that Kenya is performing relatively well because most of debt is for financing infrastructure that addresses bottlenecks which would then boost sustainable economic growth (Nord, IMF \& Ida, 2015). The Kenya National Treasury supports the argument that increased investment in infrastructure requires an increase in the level of government debt (Republic of Kenya, 2015a).

Fiscal deficits in Kenya have resulted to an increase in the share of debt service in total spending over the years due to accumulating debt stock which increases servicing amounts (Otieno, 2015). The total debt service as a percentage of GDP in Kenya was 0.9, 0.8,1.0,1.8 and 1.8 for the years 2011,2012, 2013,2014 and 2015 respectively (Republic of Kenya, 2016a). Figure 1.1 below provides a summary of debt servicing cost per Sector from the year 2003-2015. 


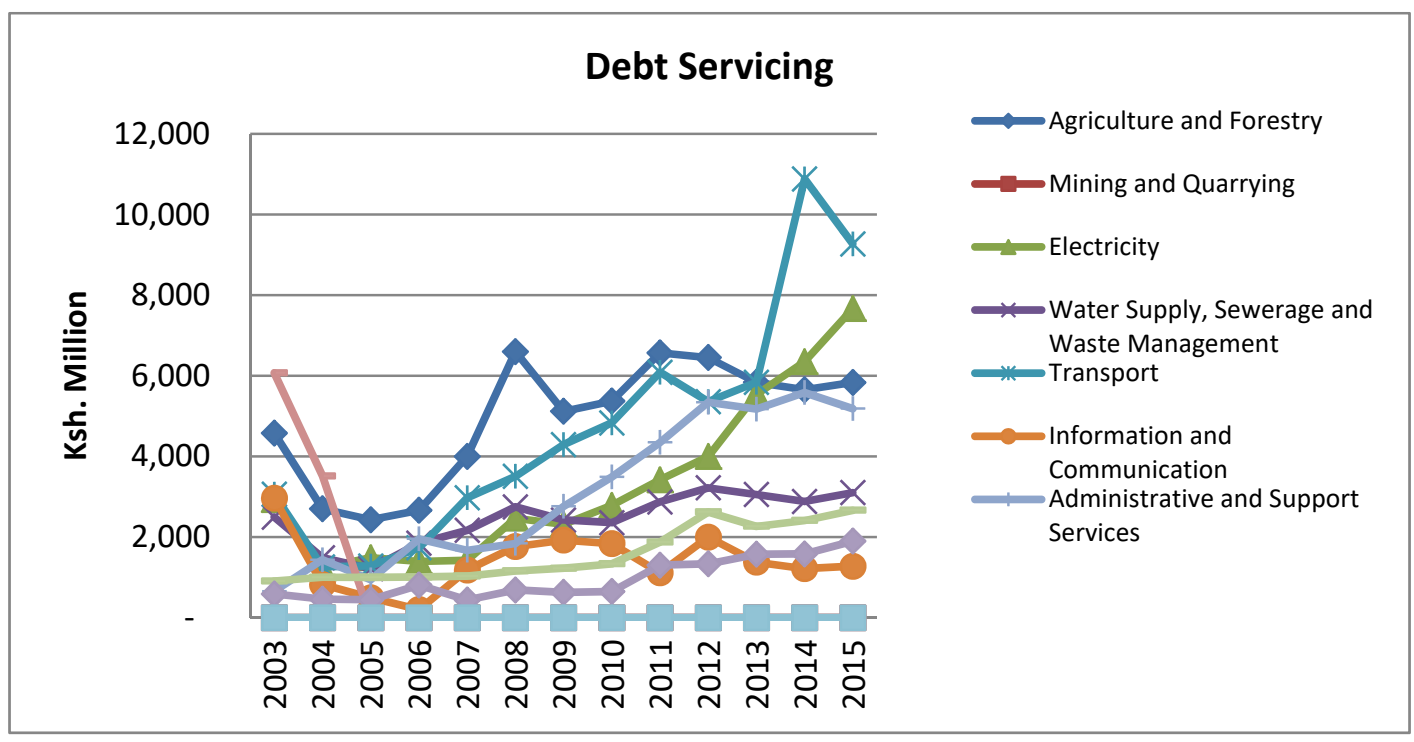

Figure 1.1. Debt Servicing Costs

Source: National Treasury Kenya (2016)

The cost of debt has been increasing in Kenya for all sectors except Mining \& Quarrying and Arts, entertainment and recreation. These are sectors that do not receive direct foreign donor support. Public Administration and Defence Sector debt servicing cost was suspended in the year 2005 because the authenticity of the external supplier credits contracted by the government of Kenya to finance security related projects had been a subject of public interest following the revelation early in the year 2004 that the Government was servicing a non-existent debt with Anglo Leasing \& Finance Company Limited (Republic of Kenya, 2007a). Government of Kenya incurs the largest debt servicing costs on Transport, Agriculture \& Forestry, Electricity and Admnistration \& Support services Sectors that implement Vision 2030 flagship projects which are expected co contribute to the 10\% GDP growth (Republic of Kenya, 2007b).

Sectoral Economic Growth in Kenya has been fluctuating over time in all the sectors. According to the World Bank (2014) economic growth in Kenya has been hindered by immense dependence on a few agricultural imports, expansion of the population, protracted drought, inadequate power supply, poor infrastructure, extreme disparities of wealth, terrorism, poor governance \& corruption and post- general election violence. Despite these challenges, the World Bank projects Kenya as one of the fastest-growing economies in East Africa, with a GDP growth rate forecast of $6.0 \%$ in the year 2015 and $6.6 \%$ in the year 2016. However, according to the World Bank, some of the impediments of growth have not been empirically tested. African Development Bank (2017) has documented that real GDP growth of 5.8\% in 2016 was robust and was driven mainly by services which accounted for $66 \%$ of growth and industry which accounted for $19 \%$ of growth. Agriculture accounted for $15 \%$ of growth, the lowest in recent years. Growth in services was driven by real estate which grew by $12 \%$ and transport and storage which grew by $10 \%$. Growth in industry was driven by construction which grew by $8.2 \%$ and manufacturing which grew by $6.2 \%$. This level of growth is way below the $10 \%$ mark level projected by the Vision 2030. However, Ayyoub (2015) argues that prevailing inflation rates in the country can impact the growth of some sectors since some respond differently to a certain level of inflation as explained by the proponents of the sectoral inflation theory. Government of Kenya uses expenditure in key sectors to spur growth (Republic of Kenya, 2007b). But even with the increase in government expenditure, which includes debt servicing, the economy has not grown proportionately with the growth in government expenditure.

\subsection{Statement of the Problem}

Kenya has been borrowing at a faster rate over the last five years to complement the budget deficit resulting from insufficient revenue collection and desires to expand the economy and infrastructure development (Republic of Kenya, 2014). For instance, external debt ceiling doubled from Ksh.1.2 trillion in the year 2012 to Ksh. 2.5 trillion in the year 2013 (Republic of Kenya, 2013). Debt servicing captures a large proportion of government expenditures and total revenue. This poses a risk to the national budget and the country's financial stability. Escalating debt levels signals that the government will in future spend a significant portion of its revenue repaying debts at the expense of key sectors in the economy (Otieno, 2015).

The government of Kenya borrows substantial amounts of money to finance Vision 2030 flagship projects that would contribute to $10 \%$ GDP growth. The loans are then shared among the sectors that implement flagship projects which include; Agriculture and Forestry, Electricity and Water Supply, Education, Health Care, National Security and Defense 
(Republic of Kenya, 2015b). This has subsequently increased the level of debt servicing in the country. Even with the increase in debt financing and the resultant sectoral debt servicing costs in Kenya, the corresponding economic growth in these sectors have been fluctuating. For example, debt servicing in the transport sector has been growing from Ksh.3.8 billion in the year 2006 to Ksh. 9.2 in the year 2015. On the other hand, the associated GDP values fluctuated between 3.0\%, 4.9\% and 7.1\% for the years 2008, 2010, and 2015 respectively. Nord, IMF and IDA (2015) and the Kenya National Treasury argues that increase in debt financing will address bottlenecks that would boost economic growth. This thus leaves it unclear whether increase in debt servicing significantly influences sectoral economic growth Kenya or not.

Emprirical literatures reviewed in Kenyan context used aggregate GDP values and government expenditure which does not clearly capture sectoral peformance with specific components of government expenditure. Hence, empiricalevidence of debt servicing and sectoral economic growth in Kenya is scanty. Consequently, this study sought todetermine the effect of debt servicing on sectoral economic growth with inflation moderating the relationship to bridge the knowledge gap.

\subsection{Objectives of the Study}

i. To determine the effect of debt servicing and sectoral economic growth in Kenya.

ii. To determine the moderating effect of inflation on the relationship between debt servicing and sectoral economic growth in Kenya.

\subsection{Theoretical Review}

\subsubsection{Debt Overhang Theory}

The earliest proponent of debt overhang theory wasKrugman (1988) who argued that a debt can trap companies and countries in a vicious downward spiral since a larger component of revenue go to servicing debt thus creating an operating deficit that can only be filled through increment debt that worsens the debt burden. A country with debt overhang will experience poor standards of living and reduced spending in key sectors such as education, health, infrastructure, and agriculture. This theory holds that debt service affects growth since it discourages private investments and alters government expenditure composition. Higher external interest rates increases budget deficit of a country which then reduces the proportion of public savings if private savings do not increase to offset the difference. This will crowd out private investments thus reducing economic growth (Clements, Bhattacharya \& Nguyen, 2003).

Moreover, Debt Overhang theory argues that there will be a possibility that future debt will be larger than the country's repayment ability, and that debt service costs will discourage further domestic and foreign investment. This is because the expected debt burdens to repay creditors is high and therefore unwilling to incur investment costs today for the sake of increased output in the future (Kobayashi, 2013). Critics of this theory argue that borrowers under-development is usually due to their resource mismanagement other than the burden of external debt, and thus debt overhang is considered as a symptom rather than the cause of low economic growth (Sichula, 2012). The level of debt servicing cost in Kenya has been on an upward trajectory over time with the highest being approximately Ksh. 74.5 billion in year 2014, up from approximately Ksh. 14 billion in 2006. This takes enormous share of government revenue that could have been expended by productive sectors in the economy. This forces the government to borrow more, which could be expensive in the long run and can trap the country in a debt overhang situation.

\subsubsection{Sectoral Inflation Theory}

Sectoral or demand shift inflation theory was put forward by Charles Schulz who pointed out that neither demand pulls nor cost push caused an increase in prices between 1955-57 in American economy (Schultze \& Mackie, 2002). Schultz pointed out that prices and wages are elastic upwards in response to excess demand but they are rigid downwards. Even if the aggregate demand is not excessive, excess demand in some sectors of the economy, deficient demand in other sectors will still lead to the general price level. The rationale is that prices do not fall in the demand deficient sectors, there being the downward inflexibility of prices. On the other hand, prices increase in the excess-demand sectors and remain constant in the other sectors. The net effect is an general increase in the price level (Smriti, 2015).

Moreover, increase in prices in excess-demand industries (or Sectors) can stretch to demand deficient industries through the prices of raw materials and labor costs.Excess demand in particular industries will lead to a general price increase of intermediate materials, supplies and components. These rising prices of materials will strecth to demand-deficient industries that use them as inputs. The demand-deficient industries will therefore increase the prices of their products to protect their profit margins (Ayyoub, 2015). The main limitation of this theory is that empirical evidence has notproven Schultz's proposition that sectoral price increases are explained by upward shifts of demand. Secondly, it fails to examine the monetary prerequisites for inflation, and elusiveness is respecting the definitions of full employment and overal excess demand (Smriti, 2015). 


\subsection{Empirical Literature Review}

Cholifihani (2008) used cointegration analysis for the period 1980-2005 to examine the long run and short run relationship between public debt service and GDP in Indonesia. The results indicated that Indonesia faces a debt overhang problem in the long-run because the increase in public external debt service slows economic growth. This study context was outside Africa and that debt specific to a sector cannot be obtained from the study. The moderating role of corruption, inflation and political risk cannot be established from Cholifihani (2008) study.

Makau (2008) employed a single equation model and estimated using OLS to examine the relationship between Kenya's external indebtedness, debt service and economic growth for the period 1970-2003. Makau (2008) study established that external debt is mainly official, of which a bigger proportion is from multinational sources. Further, the debt burden has been increasing from early 1990's. In addition, the study found that in the short run and long run debt service to GDP is positive. Makau (2008) study was conducted over a decadeago and it failed to incorporate variables that influence the relationship; that is, no moderating variable.

Maingi (2010) applied VAR estimation technique using annual time series data for the period 1963 to 2008 to evaluate the impact of government expenditure on economic growth in Kenya. Components of government expenditure used by Maingi (2010) included; investment, physical infrastructure, education, health care, public debt servicing, economic affairs, general administration and services, defense, public order and national security, and government consumption. Maingi (2010) established that public debt service and GDP had a unidirectional causality. This implies that debt service explains economic growth. The negative effect can be explained by the fact that the resources used to service public debt could have crowded out government investments in areas that could have been more productive. Also, high debt burdens could have led to domestic agents to transfer funds abroad for fear of future tax liabilities to service the debt and discouragement of foreign direct investments because the government is likely to impose restrictions on external payments. The moderating role of inflation, corruption and political risk cannot be established from Maingi (2010) study.

1.6 Conceptual Framework

\section{Independent Variable}

\section{Dependent Variable}

\section{Debt Servicing}

- Amount in Ksh.

Source: Researcher (2015)

\subsection{Research Methodology}

Causal research design has traditionally been used to determine the effect that a specific change has on existing customs and hypothesis (Trochim, 2006). Consequently, the study employed a causal research design. Given the nature of the study problem, positivist philosophy was adopted. A census eleven that receive government expenditure was carried out. These sectors include: Agriculture and Forestry, Mining and Quarrying, Electricity, Water Supply, Sewerage and Waste Management, Transport, Information and Communication, Public Administration and Defense, Education, Health, Administration \& Support Services and Arts, Culture \& Recreation sectors. The study used Autoregressive Distributed Lag (ARDL) model to estimate the effect of Debt servicing on sectoral economic growth in Kenya. The (ARDL) modeling is anchored on Pesaran, Shin and Smith (2009). Autoregressive Distributed Lag (ARDL) has the following merits; it is consistent even if there is a mixture of $I(0)$ and $I(1)$, it estimates the functional Error Correction Model (ECM) and tests for co integration at the same time and it can provide both short run and long run estimates. Hausman test was used to choose an efficient estimator among the three possible estimators, Mean Group (MG), Pooled Mean Group (PMG) and Dynamic Fixed effects (DFE) for models (1), (2) and (3). Before applying the ARDL Model, Panel Stationarity was used to check whether the stochastic process was oscillating around the constant mean over the period with some confidence intervals whereas Heterogeneity test was carried out to check whether sectors were unique.

The model

$$
\ln S G_{i t}=\beta_{0}+\beta_{1} \ln D S_{i t}+\mu_{i}+u_{i t}
$$


Where

$\mathrm{SG}=$ Sectoral economic Growth

$\ln =$ The natural logarithms operator

$\mu_{i}=$ Individual Sectoral effect

$u_{i t}=$ Is idiosyncratic error term

$\beta_{0}=$ Is a constant

$\beta_{i}^{\prime} s=$ Are coefficients for period representing lags for the current and previous year $\left(\mathrm{t}_{\mathrm{t}}\right.$ and $\left.\mathrm{t}_{\mathrm{t}-1}\right)$

DS $=$ Debt servicing

INF=Inflation

Introducing Inflation as a variable

$$
\ln S G_{i t}=\beta_{0}+\beta_{1} \ln D S_{i t}+\beta_{2} \ln I N F_{t}+\mu_{i}+u_{i t}
$$

Where $\mathrm{INF}_{\mathrm{t}}$ is Inflation in year $t$

Political Risk as a moderator

$$
\ln S G_{i t}=\beta_{0}+\beta_{1} \ln D S_{i t}+\beta_{2} \ln I N F_{t}+\beta_{3} \ln I N F_{t}^{*} \ln D S_{i t}+\mu_{i}+u_{i t}
$$

Table 1.1. Moderation Decision Making Criteria

\begin{tabular}{llll}
\hline Scenario & Model 2 & Model 3 & Conclusion \\
\hline One & $\beta_{2}$ is significant & $\beta_{3}$ is insignificant & Moderating variable is an explanatory variable \\
Two & $\beta_{2}$ is insignificant & $\beta_{3}$ are significant & Moderating variable has a moderating effect \\
\hline
\end{tabular}

Source: Whisman and McClelland (2005)

Table 1.1 above illustrates the two possible scenarios that can occur when inflation is introduced as a variable as well as a moderator. If scenario one occurs then inflation is an explanatory variable rather than a moderator. If scenario two occurs then inflation is a moderator.

\section{Results, Findings and Discussion}

The specific objective was to determine the effect of debt servicing on sectoral economic growth in Kenya and to determine the moderating role of inflation on the relationship between debt servicing and sectoral economic growth in Kenya. Table 2.1 below presents the results of the test of hypothesis.

\begin{tabular}{|c|c|c|c|c|c|c|}
\hline & \multicolumn{2}{|c|}{ PMG } & \multicolumn{2}{|c|}{ MG } & \multicolumn{2}{|r|}{ DFE } \\
\hline Variables & Long Run & Short Run & Long Run & Short Run & Long Run & Short Run \\
\hline \multicolumn{7}{|l|}{ Debt } \\
\hline Servicing & $\begin{array}{l}0.0826 * * * \\
(0.0168)\end{array}$ & $\begin{array}{l}0.0210 \\
(0.0181)\end{array}$ & $\begin{array}{l}0.0457 \\
(0.0331)\end{array}$ & $\begin{array}{l}-0.00276 \\
(0.0340)\end{array}$ & $\begin{array}{l}-0.0378 * * * \\
(0.00891)\end{array}$ & $\begin{array}{l}0.00468 \\
(0.00848)\end{array}$ \\
\hline Constant & & $\begin{array}{l}0.934 * * * \\
(0.324)\end{array}$ & & $\begin{array}{l}13.46^{* * *} \\
(4.557)\end{array}$ & & $\begin{array}{l}21.14 * * * \\
(2.533)\end{array}$ \\
\hline \multicolumn{7}{|c|}{ SPEED OF ADJUSTMENT } \\
\hline & \multicolumn{2}{|c|}{$\begin{array}{c}-0.307 * * * \\
(0.0951)\end{array}$} & \multicolumn{2}{|c|}{$\begin{array}{c}-0.984 * * * \\
(0.167)\end{array}$} & \multicolumn{2}{|c|}{$\begin{array}{c}-1.189 * * * \\
(0.102)\end{array}$} \\
\hline KEY: & \multicolumn{4}{|c|}{$\begin{array}{l}\text { Standard Errors In Parentheses } \\
* * * \mathrm{P}<0.01, * * \mathrm{P}<0.05, * \mathrm{P}<0.1\end{array}$} & & \\
\hline
\end{tabular}

Table 2.1. Effect of Debt Servicing on Sectorial Growth

Source: Research Data (2016)

$\mathrm{HO}_{1}$ : Debt Servicing has no significant effect on Sectoral Economic Growth in Kenya

The first objective sought to establish the effects of debt servicing on sectoral economic growth in Kenya. The null hypothesis $\left(\mathrm{H}_{01}\right)$ that is; debt servicing has no effect on sectoral economic growth in Kenya was tested. Table 2.1 indicates that the coefficient of debt servicing in short run is 0.0210 associated with a p-value greater than the significant level of 0.05 and $t$ statistic of 1.16 calculated as, $(0.0210 / 0.0181)=1.16$. Hence, the null hypothesis was supported at the significance level of 0.05 . Thus, in the short run debt service has no effect on sectoral economic growth in Kenya.

In the long run, Table 2.1 indicates that the coefficient of debt servicing is 0.0826 with a corresponding p-value less than the significance level of 0.01 and $t$ statistic of 4.92 obtained as $(0.0826 / 0.0168)=4.92$. Consequently, the null hypothesis was rejected. Further, debt service coefficient has elasticity given that sectoral growth and debt service 
go into model $1 \mathrm{in} \log$ form. The magnitude of the coefficient shows that other things being equal, and with a one per cent increase in debt servicing in the long run, sectoral growth increases by 8.26 percentage points.

Empirical results revealed that debt servicing has no effect on sectoral economic growth in the short run but an effect in the long, run that is; Kenya is not facing debt overhang problem. This is in support of IMF report by Nord et al. (2015) on debt sustainability analysis in Kenya and empirical findings by Makau (2008). However, Cholifihani (2008) and Maingi (2010) empirical findings were negative.

$\mathrm{HO}_{2}$ Inflation has no significant moderating effect on the relationship between debt servicing and Sectoral Economic Growth in Kenya

The moderating effect of inflation under hypothesis two was estimated using models 2 and 3 . Table 2.2 below illustrates the estimates of model 2 and coefficient of interest as per model 2 is that of inflation. On the other hand, Table 2.3 reports the estimates of model 3.

Table 2.2. Inflation as a Variable

\begin{tabular}{|c|c|c|c|c|c|c|}
\hline & \multicolumn{2}{|c|}{ PMG } & \multicolumn{2}{|c|}{ MG } & \multicolumn{2}{|c|}{ DFE } \\
\hline VARIABLES & Long Run & Short Run & Long Run & Short Run & Long Run & $\begin{array}{l}\text { Short } \\
\text { Run }\end{array}$ \\
\hline Debt Servicing & $\begin{array}{c}0.162 * * * \\
(0.0278)\end{array}$ & $\begin{array}{l}0.122 * * * \\
(0.0391)\end{array}$ & $\begin{array}{c}170.1 \\
(170.1)\end{array}$ & $\begin{array}{c}0.125^{*} \\
(0.0650)\end{array}$ & $\begin{array}{c}0.0296 \\
(0.0383)\end{array}$ & $\begin{array}{c}0.0396 \\
(0.0356)\end{array}$ \\
\hline Inflation & -0.0491 & $0.474 * *$ & 422.3 & $0.494 * *$ & $0.838^{* * *}$ & 0.271 \\
\hline Constant & $(0.130)$ & $\begin{array}{c}(0.213) \\
0.909^{* *} \\
(0.375) \\
\text { SPEED OF A }\end{array}$ & $\begin{array}{l}\text { (422.3) } \\
\text { DJUSTMEN }\end{array}$ & $\begin{array}{c}(0.231) \\
1.975 \\
(3.640)\end{array}$ & $(0.277)$ & $\begin{array}{l}(0.244) \\
-3.391 \\
(2.208)\end{array}$ \\
\hline MODEL & $\begin{array}{r}-0.4 \\
(0 .\end{array}$ & & $\begin{array}{r}-0.8 \\
(0 .\end{array}$ & $\begin{array}{l}8 * * * \\
25)\end{array}$ & $\begin{array}{r}-0.69 \\
(0.0\end{array}$ & \\
\hline KEY: & & $\begin{array}{l}\text { Standard er } \\
* * * p<0.01,\end{array}$ & $\begin{array}{l}\text { in parentl } \\
<0.05, * p\end{array}$ & & & \\
\hline
\end{tabular}

Source: Research Data (2016)

Table 2.2 above indicates that the coefficient of inflation which is of interest under model 2 in the PMG estimates is -0.0491 with a corresponding $p$-value greater than the level of significance of 0.05 and $t$ statistic of -0.38 calculated as, $(-0.0491 / 0.130)=-0.38$ in the long run. In the short run, the coefficient is 0.474 with a corresponding $p$-value less than the significance level of 0.05 and $t$ statistic of 2.23 obtained as, $(0.474 / 0.213)=2.23$. Therefore, the coefficient of inflation is significant in the short run rather than in the long run.

Table 2.3. Inflation as a Moderator

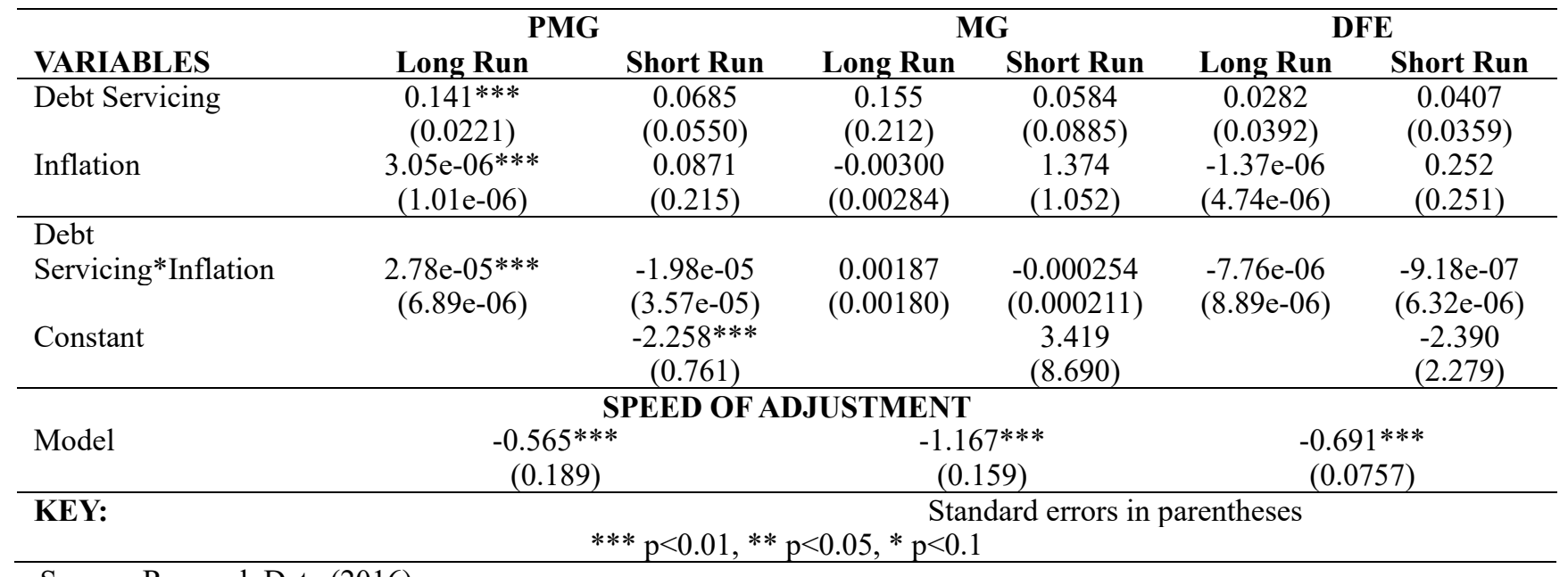

Source: Research Data (2016)

Table 2.3 above illustrates addition inflation as a moderator. The coefficients of concern are those of the interaction terms. The PMG estimates show that coefficients of all the interaction terms for debt servicing are significant in the long run. In Table 2.2, the coefficient of inflation is not significant in the long run. When these scenarios are compared to the decision making criteria in Table 1.1, the null hypothesis that inflation has no moderating effect on the relationship between government expenditure and sectoral economic growth in Kenya is rejected at the significance levels of 0.05 in the long run. For this reason, inflation has a moderating effect on the relationship between debt 
servicing and sectoral economic growth in Kenya. The ( + or -) sign of the interaction term between debt servicing and inflation reinforces that of the coefficient of debt servicing. Therefore as per expectation, inflation enhances the influence of debt servicing on sectoral economic growth in the long run.

In the short run, the coefficients of the interaction terms of debt servicing in Table 2.3 is not significant. In Table 2.2, the coefficient of inflation is significant. Comparing these scenarios with the decision making criteria, the null hypothesis (that inflation has no moderating effect on the relationship between debt servicing and sectoral economic growth in Kenya) is not rejected at the level of significance of 0.05 . Therefore, in the short run, inflation is an explanatory variable rather than a moderator. This is in contrary to the empirical findings of Loizides and Vamvoukas (2005) who established that economic growth Granger causes increases in the relative size of government in the United Kingdom when in inflation is included in the model. In the short run however, inflation is an explanatory variable rather than a moderator.

\section{Conclusion}

In view of hypothesis one, the test found that debt servicing has no effect on sectoral economic growth in Kenya in the short run. In the long run, debt servicing has an effect with a positive coefficient. This finding is supported by some studies and equally contradicted by others. The study concludes that debt servicing has a positive effect on sectoral economic growth. However, there could be other factors outside the scope of this study that could be having a significant effect on debt servicing which were not controlled in this study. The study further confirms that Kenya is not facing a debt overhang problem.

The empirical findings on the test of hypothesis two indicate that inflation has a moderating effect on the relationship between debt servicing and sectoral economic growth in the long run. Hence, the study concludes that inflation heightens the effect of debt servicing. Furthermore, inflation is an explanatory variable, rather than a moderator, in the short run.

\section{Recommendations}

Even though debt servicing has a statistically significant effect with a positive coefficient on sectoral economic in Kenya, the National Treasury should critically evaluate the need to borrow and the cost of associated debt. The study further recommends that if the government must borrow from foreign markets, then the loans must be concessional in nature with long repayment periods and lower interest rates. In addition, government of Kenya should streamline debt servicing costs since it reduces what could have been allocated to productive sectors that implement Vision 2030 flagship projects which eventually contributes to $10 \%$ GDP growth. Besides that, debt servicing crowd out private firms which will retard growth in the economy.

Inflation has a significant moderating effect on the relationship between government expenditure and Sectoral economic growth. Hence, the fiscal and monetary policy implementers should seek to maintain desirable levels of inflation based on the performance of the economy.

\section{References}

Ayyoub, M. (2015). Inflation and Sectoral Growth in Developing Economies. university of Innsbruck.

Cholifihani, M. (2008). A cointergration Analysis of Public Debt Service and GDP in Indonesia. Journal of Management and Social Sciences, 4(2), 68-61.

Clements, B., Bhattacharya, R., \& Nguyen, T. (2003). External Debt, Public Investments and Growth in Low-Income Countries (No. 03/249).

Im, K., Pesaran, H., \& Shin, Y. (2003). Testing for Unit Roots in Heterogeneous Panels. Journal of Econometrics, 115, 53-74.

Kobayashi, K. (2013). A Theory of Public Debt Overhang. Retrieved from http://hdl.handle.net/10086/25483

Krugman, P. R. (1988). Market Based Debt Reduction schemes. Cambridge. https://doi.org/10.3386/w2587

Maingi, J. N. (2010). The Impact of Government Expenditure on Economic Growth in Kenya: 1963-2008. Kenyatta University.

Makau, J. (2008). External Debt Servicing and Economic Growth in Kenya: An Empirical Analysis. University of Nairobi.

Nord, R., IMF, L., \& Ida, P. (2015). Request for Modification of Performance Criteria-. IMF. Retrieved from https://www.imf.org/external/pubs/ft/dsa/pdf/2015/

Otieno, M. (2015). Total Debt Servicing and Macroeconomic Performance in Kenya. Kenyatta University. Retrieved from http://ir-library.ku.ac.ke/ 
Pesaran, M., Shin, Y., \& Smith, R. (2009). Pooled mean group estimation of dynamic heterogeneous panels. Journal of the American Statistical Association, (94), 289-326.

Republic of Kenya. (2007a). Annual Public Debt Management Report July 2005-June 2006. Nairobi. Retrieved from www.treasury.go.ke

Republic of Kenya. (2007b). Kenya Vision 2030 - A Globally Competitive and Prosperous Kenya. Nairobi: Government Printer.

Republic of Kenya. (2013a). Comprehensive Public Expenditure Review. Nairobi. Retrieved from www.treasury.go.ke

Republic of Kenya. (2014a). Facts and Figures , 2014. Nairobi. Retrieved from http://www.knbs.or.ke/

Republic of Kenya. (2015a). Medium Term Debt Management Strategy. Nairobi. Retrieved from http://www.africanbondmarkets.org/fileadmin/uploads/afdb/Countries/Kenya/National_Treasury/Kenya_Medium-t erm_Debt_Strategy-2015.pdf

Republic of Kenya. (2015b). Budget Policy Statement 2015. Nairobi. Retrieved from www.treasury.go.ke

Republic of Kenya. (2016a). Economic Survey 2016. Nairobi.

Republic of Kenya. (2016b). Support To The Public Financial Management Reform Strategy in Kenya. Nairobi. Retrieved from www.treasury.go.ke

Schultze, C. L., \& Mackie, C. (2002). At What Price: Conceptualizing and Measuring Cost-of-Living and Price Indexes. Washington, DC: National Academic Press.

Sichula, M. (2012). Debt Overhang and Economic Growth in HIPC Countries: The Case of Southern African Development Community (SADC). International Journal of Economics and Finance, 4(10), 82-92. https://doi.org/10.5539/ijef.v4n10p82

Smriti, C. (2015). Sectoral or Demand-Shift Inflation. Retrieved October 2, 2015, from http://www.yourarticlelibrary.com/macro-economics/inflation-macro-economics/Sectoral-or-demand-shift-inflation -useful-notes-on-Sectoral-or-demand-shift-inflation/31128/

Trochim, W. M. (2006). Research Methods Knowledge Base. Retrieved from http://www.socialresearchmethods.net/kb/design.php

Whisman, \& McClelland. (2005). Designing, Testing and Interpreting Interactions and Moderator Effects in Family Research. Journal of Family Psychology, (19), 111-120. https://doi.org/10.1037/0893-3200.19.1.111

World Bank. (2014). Kenya's Economy Continues to Grow in a Challenging Environment. Retrieved July 5, 2015, from http://www.worldbank.org/en/country/kenya/publication/kenya-economic-update

World Bank. (2015). Debt Service on External Debt. Retrieved October 7, 2015, from data.worlbank.org/indicator/DT.TDS.DPPG.CD

\section{Copyrights}

Copyright for this article is retained by the author(s), with first publication rights granted to the journal.

This is an open-access article distributed under the terms and conditions of the Creative Commons Attribution license which permits unrestricted use, distribution, and reproduction in any medium, provided the original work is properly cited. 